\title{
National Memory vs Official Policy of Memory in Ukraine (in the case of Holodomor tragedy commemoration 1932-1933)
}

\author{
I. M. Shuhalyova \\ Zaporizhzhia National University \\ shug_im@ukr.net \\ R. L. Moldavskii \\ Zaporizhzhia National University \\ mold1@ukr.net
}

Key words: government policy, Holodomor, identity, memory.
In the article, the authors analysed components of the memory policy in Ukraine. During the research the influence of the memory policy on the formation of national identity and civil society was determined.

In the early 1990s, the Ukrainian government gradually institutionalised a new culture concerning Holodomor. On a government lever, the policy consecutively enhances an amount of museums, libraries, archives and other database institutions. Annually, different memorial events in the honour of the Holodomor victims. Almost in every locality, there is a memorial of a sculpture that confirms the tribute to the memory. The causality analysis of review and cinematographic film, fine arts and music discussions mast be compulsory in school educational courses in history. Taking above mentioned into consideration, it should be reasonable to insist on transforming Holodomor into the important part of national memory in Ukraine.

At the current stage in Ukraine, memory evolved into historical order, concentrating itself on imperative, hypertrophic and passionate character. However, an incredible decentralisation of the whole heritage transformed every household and every person into a collector of their personal existence due to the photographs and family documents. The above-mentioned point of view was approved due to the interviewing of witnesses who survived the tragedy of 1932 - 1933.

Modern Ukrainian society, especially the majority of older generation, went survive many hardships and hearth of Holodomor. These tragic occurrences were remembered and cherished in their memory forever. The assumptions were confirmed during the ethnographic expedition which was held on the basis of Zaporizhzhia National University where we took place in. Hereby, memory is definitely one of the central conceptions of national identity. However, loss of memory is a peculiarity of loss identity.

\section{Народна пам'ять vs офіційна політика пам'яті в Україні (на прикладі комеморіації трагедії Голодомору 1932-1933 рр.)}

I. М. Шугальова

Запорізький національний університет

\section{Р. Л. Молдавський}

Запорізький національний університет

Ключові слова: Голодомор, пам'ять, ідентичність, державна політика.
Автори статті проаналізували складові політики пам'яті в Україні. 3'ясували впливи політики пам'яті на формування національної ідентичності та громадянського суспільства.

Можна обґрунтовано стверджувати, що Голодомор перетворився у складову національної пам'яті. Люди старшого покоління пройшли через горнило Голодомору. Ці трагічні події закарбувалися в їх пам'яті. Отже, пам'ять $€$ дійсно одним із центральних понять в дослідженні Голодомору. Пам'ять $€$ центральна складова національної ідентичності. 
A historian is made by history more than a historian makes history. Humanitarian catastrophes, such global as Holodomor (famine-genocide) of 1932 - 1933 was, have changed national consciousness and identity of Ukrainians insomuch that only nowadays this change in memory and history connection is taking place. Pierre Nora, a French scientist who has focused on the features of national memory in France, noticed that national memory is a conversion of a deep historical memory due to the invasion of memory groups [1, c. 15].

Holodomor 1932 - 1933 in Ukraine will always be remembered by many Ukrainians as one of the most dreadful pages of our history. Mostly, the public considers those tragic and painful events on an emotional level. At the same time, famine-genocide is a historical phenomenon which happened in a particular time, place and is a result of actions of particular people.

The tragedy of 1932 - 1933 has been so largescale as in historiography is identified with its own name "Holodomor" (famine-genocide) [2, p. 183 220.]. According to Andrea Graziosi, a professor of history in Naples University, the term "famine-genocide" (which is different from a neutral meaning "famine" as it underlines a deliberate character of decimation) was used by an author Oleksa Musiienko within his performance on a party meeting of the Ukrainian Writers Union which was published in "Literaturna Ukraina" (Literary Ukraine) on 18 February 1988 [3].

The topic of Holodomor 1932 - 1933 has been popularised quite recently, in 1980s. The tradition of interpretation regarding the events of 1932 1933 in Ukraine as a genocide was launched by Ukrainian historians in diasporas. At the beginning of 1980s, on the occasion of the 50th Holodomor anniversary the series of investigations, which identified the famine 1932 - 1933 as a genocide and holocaust, was published. The names of these studies speak for themselves - "the Great Famine in Ukraine: unknown Holocaust: dedicated to the commemoration of the 50th anniversary of the Ukrainian Famine 1932 - 1933" [4], “The artificial famine 1932 - 1933" [5], "The Famine-Genocide 1933 50th anniversary in Soviet Ukraine" [6], "50 years ago: Famine Holocaust in Ukraine: terror and human suffering as an instrument of Soviet Russian imperialism" [7].

The aim of the article is to analyse the genesis of the official policy for the memory in the independent Ukraine regarding the commemoration of Holodomor 1932 - 1933 victims as well as to define the policy comprehension by ordinary Ukrainians.
It should be mentioned that both research and immortality of memory issues were initiated by foreign Ukrainians. Globally, first memorials for the victims of Ukrainian Holodomor appeared on the occasion of the event 50th anniversary due to the initiatives of Ukrainian diasporas in the USA and Canada (for example, in Edmonton 1983, Winnipeg 1984).

In Ukraine, tradition of commemoration began at the beginning of 1990 s due to the initiative of active public. At best, the local government institutions "ignored" such events. At worse, they carried out campaigns of ideological harassment (even in 1990s!).

Till the recent time, professional exhumation and reburial of the victims has been a rare phenomenon due to the lack of resources, experts and government noninterest.

At the beginning of 1990s, the Ukrainian government gradually institutionalised the new nominal culture. Every year, memorial events aimed at the commemoration of Holodomor victims are held in Ukraine. Almost every locality has a memorial or a sculpture which confirm tribute to the memory. School educational courses in history include compulsory causality analysis, review and discussion of cinematographic films, fine arts and even music (the opera "Read Earth" is meant). Taking above mentioned into consideration, it should be reasonable to insist on transforming Holodomor into the important part of national memory in Ukraine.

At the current stage, the meaning "inheritance" is gradually being displaced in Ukraine. The process of the past transformation into memory is being occurred. Memory is changing into the historical state focusing on its imperative, hypertrophied and passionate character.

The researcher P. Nora has given an appropriate specification for one of the historical memory's peculiarities saying that "the imperative character is connected not only with memory obligation that captures the era in a moral sense but deeper and more generally with that can be called the acceleration of history, the ever-faster change of things, the remoteness of the past, as well as sense of loss. At this stage, conservatism, phenomenal expansion of the obligatory inheritance take place so that everything is mentioned by a sign of memory in a certain way $[1$, c. 69].

The government policy for memory directed on the international recognition of Holodomor as a genocide against Ukrainian people and victims' commemoration had controversial consequences. Considering the above mentioned, a Ukrainian sci- 
entist Heorhii Kasianov should be mentioned. Dedicated to the memory policy in Ukraine, in one of his studies the author analysed the dynamic attitude towards the Holodomor victims' commemoration of the Ukrainian Presidents, beginning with the "narrative commemoration" policy, was founded by the 1st President Leonid Kravchuk till the soviet and nostalgic adaptation of the historical memory by Leonid Kuchma (though scientist tends to think that during 1994-2004 the ambivalent model of historical memory had been implemented). During the presidency of Viktor Yushchenko, so-called "canonical" variant of the historical memory was established. As a result, in 2005 - 2010, the basis of the historical memory segments was formed. Since that time, the Ukrainian tragedy has been discussing in public on the international level. The case of the Holodomor recognition as a genocide gained a large-scale popularity. The Mr. Yushchenko's follower - Viktor Yanukovych vice versa revived the Mr. Kuchma's model. Consequently, on April 2010, Mr. Yanukovych rejected officially from the importance of the Holodomor recognition as a crime against the Ukrainian nation. Generally, humanitarian direction (let his policy be called like this) of Yanukovych's activity as a president of Ukraine became a stage of historical myth-making process and nostalgia for the soviet ideologists. The current president of Ukraine Petro Poroshenko tries to support and develop national paradigm of the historical memory. For example, in the framework of de-communisation, many memorial events are realised, new historical and cultural practice are formed.

On a public level, the government policy is actively enhancing theme museums, libraries, archives and other institutions for database. However, decentralisation of all heritage instances transformed each household and each individual into a producer of the archive, collectors of their personal existence due to family's photographs and other documents. Every person transformed into an archivist of their personal identity. One of the respondents' story, by Liubov Petrivna Reznik should be reminded. Due to her life circumstances (first she lived in an infant house in Zaporizhzhia where her mother worked as a nurse who then suicided, then were homelessness and poverty life, obligation for correctional labour in Germany, then soviet imprisonment with a political reason sentence). Almost 10 years, Ms. Liubov Reznik had been trying to renew the history of her life asking for courts and archives, collecting tons of documents. The main goal of the woman was a desire to find out the correct date of her birth. Meanwhile, she managed to restore (and gave us) a lot of historical facts connected with Zaporizhzhia city generally as well as with work activity of nursery in the Rosa Luxemburg street, which tragedy we have already mentioned several times and our respondent just confirmed our knowledge.

Nowadays, modern society has an opportunity to observe a new attitude of our information society towards time, the connection transformation with the past, present and future. Previously, when time was perceived linearly, the present was a bridge between the past and the future. At the present time, the line has been disturbed so that the future began unexpected but the past began extremely enigmatic.

The Proclamation of a Holodomor's large-scale character through the artistic and cinematic images had a crucial role in Ukrainians' awareness regarding the large-scale area of Stalin regime's crimes. Tetiana Zhurchenko asked a well-directed rhetoric question: whether such policy promoted the strengthening of democracy, rule of law, and the human rights' respect in Ukraine? Answering the question herself, Ms. Zhurchenko claimed: "De-communization, declared by the President Yushchenko, had no influence on political reforms, as well as commemoration of the Holodomor victims became a symbolic replacement of a real justice" [9].

Along with that, the discussion around the extent of Holodomor divided Ukrainian society into. All official memorial events converted into a source for conflict in the society. The formal reason for such discussions is an aesthetic aspect of memorial complex and theirs value.

We do not intend to evaluate the recently mounted memorial sculptures from the aesthetic point of view but we came across the memory of Mariia Trokhymivna Zahorska, a citizen of Zaporizhzhia oblast, who survived Holodomor when she was 10-year-old child. During the interviews, Mariia Trokhymivna noticed "... When earlier we ate grass, for example, caspella (Ukrainian name is hrytskyki) and goatbeards (Ukrainian name is kozelyki), almost each of us knew where gopher hides its seeds. We knew the value of a rusk! Don't Ukrainian children who nowadays buy loafs of bread in a fantastic bright packages know a genuine value of it, finely cut and toasted with various food additives? I am definitely sure that in every Ukrainian village (if it still exists) the government must raise a monument to the rusk!" [10]. Eclectic and complex sculpture composition unlikely could reproduce that horror that children passed through in the years of Holodomor in 1932 - 1933.

Modern Ukrainian society, especially the majori- 
ty of older generation, went survive many hardships and hearth of Holodomor in 1932 - 1933 or the famine in 1946 - 1947. These tragic occurrences were remembered and cherished in their memory forever. We confirmed these assumptions during one of the ethnographic expeditions which are held regularly on the basis of the Historical faculty of Zaporizhzhia National University where we took place. In summer 2017, within the framework of an annual expedition, we had been interviewing citizens of the village Kinsky Rozdory and Voskresenka (Polohy region, Zaporizhzhia oblast). As soon as all respondents realized the aim of our visit, they immediately started talking about Holodomor of 1932 (people of older generation) or about famine in 1946 - 1947 (respondents born in 1930s). Therefore, even the repressive policy of the Soviet government directed towards the "memory oppression" could not completely erase the memory of fear and the constant feeling of hanger.

At the present time, it is not about the procedure for recognising Holodomor 1932 - 1933 as a genocide. It is obvious despite the fact of the judicial evidences' presence or absence. Currently, the most essential is a search for historical truth and preservation of national memory. It is not the only retrospect but determination of a future direction too.

The policy of memory is quite a delicate definition. There are hundreds of scientific articles and books dedicated to this topic. We genuinely hope them to have their readers. There are regular political protests which originate from the totalitarian Soviet state, there is a sense of state lining.

Nevertheless, alive national memory embodied in the memory of eyewitnesses in respect to bread and grain, as well as in the light of a candle. It should be noticed that the initiator of all-Ukrainian civil action "Light a Candle of Memory" was created by James Mace - a scientist whose contribution to the Ukrainian historical science is unprecedented.

He is the first who drew attention to a complexity of the memory policy implementation in Ukraine. Mr. Mace claimed that Stalin's policy of socially burnt ground provoked the elimination of traditional Ukraine in 20s century. In fact, it turned out a split the generations between and inside. For not significant but still presented part of the society it is important to glorify Pavlyk Morozov. For others as a pioneer Pavlyk as his followers became images of eliminated families and forged fates [11, p. 75].

Working on the topic of the research, we came across the evidence that possibly may demonstrate the analysis of the situation in Ukraine. The evidence of Ukrainian emigrant collected in the framework of the investigation of the US Congress Commission.

The testimonies of Vasyl Onufriienko, who was born in 1920 in the village Kyshetsy in Poltava oblast [12, p. 1563-1580]:

...Executioners!

When will you pay the retribution

For savage death you gifted us?

When will the heavy mist of fraud fall off

Which covered all around?

Oh! It will be pay back brutal time!

You have to be afraid!

We're still alive, we're still so strong!

You won't to be escaped!

Our blood dried up forever on your hands!

The poem was written in 1973.

Question (Q): Do you think famine had a psyche influence on Ukrainian people?

Answer (A): I don't think. So because many of those people who survived it are already died in Ukraine. Other old are dying but young generation know nothing about famine.

Q: I mean that question I'm asking... or people didn't talk with their children about it or they didn't remind it?

A: They didn't, sorry. You see, there was nothing to talk with children about as children survived it themselves, later...

Q: No. Supposing they who survived... and their children were born after famine. Or do you think that in Ukraine was concerned the topic of that famine? Officially, it didn't exist though unofficially do people know that it was?

A: Oh, yeah. Unofficially yes but if we compare it with the 1933, you see. The 1933 doesn't seem to be a famine, great famine, small famine or else. But the 1933, the only its figures became a symbol of the great national misfortune of Ukraine. What if once someone told you "the year 1933" you understood immediately what it had been meant.

Q: So, it means... You think that most of the people in Ukraine know what a famine is...

A: Everybody knows but the thing is that some people survived meanwhile others didn't. Just know it from books.

Q: Well, I think that in Ukraine they can't know it from books as there is nothing written about it.

A: I disagree as it is. Let's discuss, supposing, that novel... let me say... this passage. Well, from now it was 15 years ago. There's one, let me say, who was taken off from work by a party member because that...told the 1933's year. So, he only told "1933" there and a book was published then. Then again, there were such conversations, for example, judging 
someone. There was a head of a collective farm and he beat one woman to death as she used to steal spikelets...

As T. Boriak neatly remarked, the problem of a balance between memory and oral history could be resolved into several components: types of memory which take part in the process of the oral history recording, influence on the memory ageing, as well as individual's ability to "pull out" events from their mind [13, c. 42].

Keeping memory about the children who were placed in government custodies for children and died in the years of Holodomor is a matter of honour and human dignity. The humanitarian catastrophe of 1932 - 1933 has focused attention not only on historical or ceremonial aspects but on keeping memory about it, children's suffering too. It will become a key aspect for national self-preservation and overcoming from post-genocide syndrome. As it has been already mentioned, one of the features of the Soviet society was fear. People's consciousness, who survived that tragedy, is penetrated thoroughly. Almost half of a century, any information about famine in Ukraine was hidden carefully. At present days, the information vacuum has already been overcome. Therefore, we still are not able to identify burial places of famine deads precisely. Nowadays, still all sources (physical or investments are meant) have not been directed towards the creation of a high-quality conception for the memory policy implementation. Currently, we are talking about intellectual resources, personal involvement which could unite people around reservation of honour and memory of all lost.

In this case, one aspect should be mentioned that is a harmful memory. $\mathrm{H}$. Kasianov was sure remarked that scientists firstly predict that harmful memory must be restored. At the same time, psychological state of an eyewitness is not always considered. Whether this person agrees to experience this nightmare again describing their impressions.

Such questions are a matter of morality and ethic and do not have a single answer. Therefore, these issues are topical and their transformation into a dimension of forgetfulness is incorrect.

Consequently, memory is definitely one of the most important definition in the research of Holodomor. As $\mathrm{H}$. Kasianov remarked, memory is a central part of national identity. Loss of memory is a sign of lost identity.

Memory is as collective as individual. We can be invoked: there are thousands of publications, hundreds of memorials and so on... We refer to not only a physical demonstration of commemoration- al events. For example, give the answer themselves - do you light a candle of memory on every last Saturday in November? Do you know where is the memorial monument located in your village or city? Do you keep in your memory a name of even one lost in the years of Holodomor?... Possibly, these questions are primitive, out-of-time in the information era or, maybe they could help stop and think about...

The amount of memorial events or centres is not an indicative factor. For instance, the infant house in Zaporizhzhia we began our research with.

Even when Ukraine gained independence, a memorial tablet, which was mounted on the front of the former Infant house in Zaporizhzhia, had faced numerous obstacles for a long time. As it was mentioned above, first facts about children deaths were disclosed in 1993. In 2013, during the scientific research (which is currently finished), the amount of victims in this orphanage was identified that accounts 788. Initiative public in Zaporizhzhia suggested mounting a memorial sign on this building. However, before the Revolution of Dignity of 2014 a permission for such actions had not been given by city authorities. The point did not financial issue as many volunteers had raised funds, authorities had just been expected for giving allowance. Unfortunately, post-communist bureaucratic system had delayed this significant step for Ukraine and Zaporizhzhia as well for years. However, human's memory was able to overcome the obstacle. After the Revolution of Dignity in autumn 2014, on the front of the building № 7 in the Oleksandrivska street (a former Rosa Luxemburg street, 7) in the honour of lost children due to the Holodomor 1932 - 1933 the memorial tablet was finally established. It should be noticed that the process of commemoration continues. In 2016, a new documentary “The Last Lullaby" was presented and soon broadcast on Zaporizhzhia National Television Channel called "Zaporizhzhia" and a local channel "TV-5". Scientists, experts, regional ethnographer, relatives of witnesses disclose events' details that occurred in the Infant House in Zaporizhzhia. For many locals this documentary became a reveal of the events which happened 80 years ago in the city centre.

Tragic fate of children in Myrhorod orphanage, which has been already mentioned, was commemorated due to founding of a cemetery by passionate citizens, as well as organising a memory-museum of Holodomor by 0 . Dzhun who was an initiator and head of the museum. The problems had followed volunteers too. The government of that time had made attempts to erase memory about 
the orphanage. In 1934, archives were burnt and a new boarding school for deaf people was founded on that place. Those who survived the Famine were accommodated to orphanages. Then, there were a four-class school and a library. In 1960s, on the yard of the secondary school №4 graves of the Famine victims were revealed due to the digging ground for constructing a shooting pitch. Upon an initiative of Valentyna Oleksandrivna Seredova, the deputy headmaster of school № 4, the burial place of Holodomor victims was cleaned carefully. Olia and Serhii Horiunovs arranged a graveyard area. Impassionate people such as Lidiia Semenivna (Sydorenko) Khorokets, Anatolyi Fedorovych Kolodnii, Mariia Markivna Demchenko organised a place for a memorial. They planted trees and bushes, made a fence, installed a graveside metal pyramid and made an improvisational handmade embankment. Burial service has been undertaken since 1992. In 2009, in the former Lychansk orphanage (Ierkivska street, 31) a memorial museum for Holodomor victims was established. Present-day officials create obstacles for giving a permission to rebury a part of children who were buried on the bank of the Khorol river where there are two former gunpowder cellars overgrown with grass. In 1932 - 1933 children's corps were taken there. Official authorities explain the prohibition of exhumation due to a danger to proliferate epidemics and illness that victims had suffered from.

Citizens of Myrhorod town likewise mirror difficulties of the commemoration policy on the micro level. Not everyone supported the idea of the museum and cemetery organisation. 37-year-old citizen Inna Posieva told in her interview about the plans of a public: " 0 n this place we intend to make a playground, - she is pointing on the territory of a former orphanage. -They don't allow. They say that somewhere here human bones are. Though, I have heard that kids used to bury under the spruce, there where rocks are. We were suggested having an area behind the cemetery, we want definitely here though. But the only thing is horrible. Some says that a priest who used to look after those children couldn't stand it and hung himself" [14]. At the present days, the territory near the museum is converted into the "Square of Sorrow" where all the memorials are located.

Hereby, even in a modern opinion it is possible to face ideological barriers which overcoming is still ahead. In 1993, S. Kulchytshii wrote that awareness of Holodomor would lead to the reconsideration of the whole history of 20s century [15]. The process of reconsideration "...deprives a person from all adopted fault principles, helps respond to the fast-moving present-day events as well as keep a peace of mind in an adequate way" [15].

The phenomenon of historical memory lies in its indestructability what reassures. Although the government officially had made attempts to cover up their crime, embellish life in the Ukrainian village in 1930s, make people forget anything about Holodomor using a force, in an oral tradition and family memory the remembrance of the tragedy has kept. A sorrowful humor has tightly taken roots in Ukrainian folklore:

Near Psel where steep hill is

Geese were swimming there

Hanger people crying out

When returning then.

When cornflowers, pretty flowers

Blooming in a steppe

All my children, lovely children

Gone away in bed [16, c. 277].

Moreover, our society are not often ready to perceive information on the tragedy. Unfortunately, to recall Holodomor mostly during memorial events is a tradition. Information space is being full of TV-shows, "spotlight interview" and other theme events though after 2 or 3 days the topic pass away for the next time. Nevertheless, unknown adults and children died during Holodomor are still lie inside unknown mass burial grounds.

Mr. Nora, a French scientist of political characteristics, noticed that a formation process of generic memory derives during the last three decades [ 1 , p. 17]. Its essential mechanism is called an acceleration of history which means that anything can disappear faster at any time, future becomes more uncertain. As a result, shadowing future superimposes on shadowing past which is marooned from us forever so we are doomed to memory. Nobody knows where we direct to or come from. He introduced into scientific discourse a definition "places of memory" which are locations provided with social memory that means historical and generational memories. If manuals, history, people, government can manipulate, forget or keep historical facts in silence, the earth saves knowledge in itself and becomes a memory bearer.

Mr. Mace was sure considering that a dilemma of modern Ukraine is an absence of no way back as well as confusion of society in search of a way forward. On the one hand, we observe a consolidation of Ukrainian independence. On the other hand, we observe world processes' integration.

Activity regarding disclosure of all aspects of the tragedy continues and we hope the memory 
about innocent children who during the Holodomor 1932 - 1933 were in orphanages, will be always remembered by next generations. Obviously, the criteria of a large-scale tragedy are not the only figures but the ability of everyone to sympathize sorrow of others too. The comprehensive character of this national humanitarian catastrophe can only be realised by a deep internal upheaval of everyone who considers themselves as a civilised person.

\section{References:}

1. Нора П. Теперішнє, нація, пам'ять / Пер. із фр. А. Рєпи. Київ : ТОВ «Видавництво «Кліо», 2014. 272 с.

2. Jahn E. On the Phenomology of Mass Extermination in Europe. Osteuropa. 2005.

3. Грациози А. Советский Голод и украинский Голодомор. Отечественные записки. 2007. № 1.

4. The Great Famine in Ukraine: The Unknown Holocaust: In Solemn Observance of the 50th Anniversary of the Ukrainian Famine of 1932 - 33 / Compiled by Roma Hadzewycz, Georg B. Zarycky, Marta Kolomayets; foreword by Omeljan Pritsak. Jersey City, N.J.: Ukrainian National Association for the National Committee to Commemorate Genocide Victims in Ukraine 1932 - 33, 1983.

5. Kot-Samp L. The Artifical Famine 1932 - 1933 Shtuchnyi holod. South Bound Brook, N.J.: Ukrainian Orthodox League of the United States of America, Ukrainian Affairs Committee, 1982.

6. 50-te Anniversaire: La Famine-Gŭnocide de 1933 en Ukraine Sovitique. Paris : Comith̆ Central des Organisations Ukrainiennes en France, 1983.

7. Dushnyck W. 50 years Ago: The Famine Holocaust in Ukraine: Terror and Human Misery as Instruments of Soviet Russian Imperialism. Foreword by D. G. Dalrymple. N-Y. Toronto: World Congress of Free Ukrainians, 1983.

8. Касьянов Г. Past Continuos: історична політика 1980-х - 2000-х: Україна та сусіди. Київ : Лаурус, 2018. 420 с.

9. Журченко Т. Вшановуючи голод як геноцид: суперечливі значення меморіалів жертвам Голодомору. Україна модерна. URL: http://uamoderna.com/md/zhurzhenko-holodomor-memorials. Дата доступу 22.12.2017

10. Свідчення Загорської Марії Трохимівни, 1923 р.н. с. Просторе Чернігівського району Запорізької області. Записала Копоть І. А., 2008 р. Голодомор 1932 - 1933 років на території Запорізької області: свідчення очевидців / Упорядники Ф. Турченко, І. Шугальова, 0. Стадніченко, В. Ткаченко, О. Ігнатуша. Запоріжжя : Дике поле, 2010. 352 c.

11. Мейс Дж. Україна: матеріалізація привидів / Упор. Н. Дзюбенко-Мейс. Київ : ТОВ «Видавництво Кліо», 2016.

12. Свідчення Василя Онуфрієнко (UFRC14), 1920 р.н., с. Кишеці Полтавської області. Investigation of the Ukrainain famine 1932-1933. Oral history project of the commission on the Ukraine famine / edited for the Commission by James E. Mace and Leonid Herets / Adopted by Commission, June 20, 1990. Vol. III. Washington : United States Government Print office, 1990.1734 p.

13. 1933: «І чого ви ще живі?» / Упоряд. Тетяна Боряк. Київ : ТОВ «Видавництво «Кліо», 2016. 720 с.

14. Бабенко І., Скриль Д. «Від голоду кишечки у дітвори були тонкі, як плівочка. Від кропиви, калачиків і трави розривало нутрощі». Країна. 2017, 21 листопада. URL: https://gazeta.ua/articles/events-journal/_vid-golodukishechki-u-ditvori-buli-tonki-yak-plivochka-vid-kropivi-kalachikiv-i-travi-rozrivalo-nutroschi/805024 Дата доступу 22.12.2017

15. Кульчицький С. Геноцид. Демократична Україна. 1993, 10 червня.

16. Ревегук В. Полтавщина. Протибільшовицький Рух опору 20 - 30-х років XX століття: Нариси історії. Полтава : Полтавський літератор, 2016. 306 с. 